\title{
APLIKASI MOBILE LEARNING BERBASIS ANDROID SEBAGAI MEDIA PEMBELAJARAN PADA MATERI PROGRAM LINEAR KELAS XI DI SMA WIDYA DHARMA SURABAYA
}

\author{
Ira Wulan Sari ${ }^{1}$, Sumuslistiana ${ }^{2}$ \\ ${ }^{1,2}$ IKIP Widya Darma Surabaya \\ ${ }^{1}$ sheira.ws@gmail.com, ${ }^{2}$ sumuslistiana@gmail.com
}

\begin{abstract}
ABSTRAK
Penelitian ini memiliki tujuan untuk mengetahui aplikasi mobile learning berbasis android sebagai media pembelajaran yang berkualitas sehingga memudahkan siswa untuk mempelajari materi tersebut, serta meningkatkan hasil belajar siswa kelas XI SMA Widya Dharma Surabaya pada materi program linear. Jenis penelitian ini berupa pengembangan dengan model Hannafin dan Peck yang terdiri dari tahap analisis kebutuhan (Needed Asses), tahap perancangan (Design) dan tahap pengembangan/implementasi (Develop atau Implementation). Tempat dan subyek penelitian untuk melakukan uji coba terbatas di Sekolah Menengah Atas Widya Dharma Surabaya kelas XI, dengan subyek penelitiannya sebanyak 20 siswa dengan kemampuan yang heterogen. Metode dan teknik analisis data penelitian untuk melihat berkualitas baik tidaknya aplikasi tersebut dengan mengacu pada Nieveen yaitu analisis kevalidan, analisis kepraktisan, dan analisis keefektifan aplikasi mobile learning berbasis android sebagai media pembelajaran dalam meningkatkan hasil belajar siswa kelas XI Sekolah Menengah Atas Widya Dharma Surabaya pada pokok bahasan Program Linear. Hasil dari penelitian yang dilakukan, bahwa Aplikasi yang dibuat dapat dikatakan: (a) valid oleh para validator ahli materi dan media dengan rata-rata penilaian seluruh aspek sebesar 3,37; (b) praktis, melalui rata-rata penilaian seluruh aspek oleh guru mitra sebagai pengguna I sebesar 3,36 dalam kategori valid dan memenuhi kelayakan untuk digunakan baik oleh para validator ahli materi dan media, serta pengguna I; (c) efektif, melalui rata-rata hasil penilaian uji kompetensi para siswa sebagai pengguna II berdasarkan perhitungan N-Gain sebesar 0,70 dalam kategori tinggi dan rata-rata hasil angket respon para siswa sebesar $82 \%$ dalam kategori respon positif. Dengan demikian dapat disimpulkan bahwa aplikasi mobile learning berbasis android sebagai media pembelajaran yang bernama Prolin Edu App dapat dikatakan berkualitas baik.
\end{abstract}

Kata kunci: aplikasi mobile learning berbasis android, hasil belajar, program linear.

\begin{abstract}
This research aims to find out android-based mobile learning applications as a quality learning media that makes it easier for students to learn the material, wherever and whenever, as well as improve the learning outcomes of class XI SMA Widya Dharma Surabaya on linear program material. This type of research is in the form of development with a hannafin and peck model which consists of the needed access stage, the design stage and the development / implementation stage. Place and subjects of this research at Widya Dharma Surabaya High School in class XI, with 20 research subjects with heterogeneous abilities. Methods and techniques for analyzing research data to see whether the application is of good quality by referring to Nieveen's opinion is validity analysis, practicality analysis, and effectiveness analysis of Android-based mobile learning applications as a medium of learning in improving student learning outcomes in class XI Widya High School Dharma Surabaya on the subject of the Linear Program. The results of the research conducted, Applications that can be used: (a) valid, by validators of material and media experts with an overall average value of 3.37; (b) practical, almost on average all parts of the category are valid and fulfill their feasibility by material and media expert validators, and users I; (c) effective, precisely the average results of students as II users based on N-Gain calculations of 0.70 in the high category and the average results of the questionnaire responses of students by $82 \%$
\end{abstract}




\section{Ira Wulan Sari', Sumuslistiana ${ }^{2}$}

in the positive response category. Thus it can be concluded that the Android-based mobile learning application as a learning media called Prolin Edu App can be said to be of good quality.

Keywords: android-based mobile learning application, learning outcomes, linear program.

\section{PENDAHULUAN}

Perkembangan teknologi dan media yang semakin canggih mempermudah kita untuk mempelajari dan melakukan sesuatu. Pembelajaran yang memanfaatkan kecanggihan teknologi adalah mobile learning, sebagaimana Ally (2009) menyatakan bahwa mobile learning adalah pembelajaran melalui teknologi mobile wireless yang memungkinkan setiap orang untuk mengakses informasi dan materi pembelajaran dari mana saja dan kapan saja. Peserta didik dapat mengatur sendiri kapan dia mau belajar dan dari mana saja sumber belajar yang diinginkannya.

Salah satu satuan pendidikan yang dapat memanfaatkan teknologi dan media adalah jenjang Sekolah Menengah Atas. Para siswa pada jenjang ini berusia remaja antara 15-18 tahun yang sedang ingin mengetahui banyak hal yang baru di sekitar mereka, melalui smartphone yang sebagian besar telah dimilikinya. Namun pada kenyataannya, pemanfaatan smartphone untuk media pembelajaran dalam jenjang ini masih minim, khususnya pada pembelajaran matematika.

Berdasarkan hasil analisis yang dilakukan sebelum pelaksanaan penelitian melalui penyebaran angket respon dan wawancara dengan beberapa siswa kelas XI di akhir semester genap tahun pelajaran 2017/2018 didapatkan bahwa: (1) sebagian besar dari mereka sudah menggunakan smartphone yang berbasis android dan mampu mengoperasikan dengan baik; (2) media pembelajaran yang berbasis teknologi yaitu smartphone jarang penggunaannya (hanya sebagai alat bantu hitung) dan terkadang menggunakan LCD; (3) pembelajaran matematika di sekolah mereka, cukup menyenangkan walaupun terkadang membosankan hal ini tergantung pada materi yang dibahas; (4) salah satu materi matematika yang mereka anggap sulit adalah Program Linear, karena Materi Program Linear ini termasuk materi yang baru bagi mereka; (5) sebagian besar siswa berharap adanya media pembelajaran berupa aplikasi pada smartphone yang dapat memudahkan dalam memahami dan menyelesaikan masalah pada materi matematika yang mereka anggap sulit disertai dengan latihan soal. 


\section{Aplikasi Mobile Learning Berbasis Android Sebagai Media Pembelajaran pada Materi Program Linear Kelas XI di SMA Widya Dharma Surabaya}

Android adalah sebuah sistem operasi yang digunakan untuk mendukung perangkat smartphone, dimana setiap orang bebas menggunakan dan mengunduh source code android secara penuh. Sebagaimana menurut Safaat (2012) bahwa android menyediakan platform terbuka bagi para pengembang untuk menciptakan aplikasi mereka sendiri yang akan digunakan untuk berbagai macam piranti lunak. Aplikasi mobile learning berbasis android yang terdapat dalam smartphone secara inovatif dapat dijadikan sebagai media pembelajaran matematika yang membawa informasi setiap siswa secara mandiri untuk mencapai kecakapan dan kemahiran matematika, khususnya materi Program Linear.

Penelitian Purbasari (2013) menghasilkan sebuah aplikasi android sebagai media pembelajaran matematika pada materi dimensi tiga untuk siswa SMA. Aplikasi tersebut, selain dapat dioperasikan di android, juga dapat dioperasikan pada komputer/laptop yang berbasis windows. Kemdikbud (2013) juga menyediakan aplikasi android mobile tutorial matematika yang dapat diunduh secara bebas melalui link website www.kesekolah.com. Di dalamnya terdapat berbagai materi matematika yang dikemas dalam mobile tutorial. Namun, pada website tersebut belum tersedia aplikasi android sebagai media pembelajaran pada materi Program Linear.

Materi Program Linear merupakan salah satu bahan materi pelajaran matematika yang ditujukan untuk siswa SMA dan sederajat sesuai kurikulum 2013 dan diajarkan di kelas XI. Materi Program Linear ini termasuk materi yang baru bagi mereka, karena di jenjang sebelumnya para siswa tersebut belum mendapatkannya. Namun, Program Linier merupakan salah satu materi matematika yang penting karena materi tersebut terdapat juga di jenjang perguruan tinggi, selain itu banyak pemanfaatnya dalam kehidupan nyata seperti di bidang ekonomi, industri, dan lain-lain. Kegiatan yang memanfaatkan program linear salah satunya di Bidang ekonomi, misalnya untuk mengetahui berapa pendapatan maksimum dan ongkos minimum yang harus dikeluarkan agar mendapat keuntungan yang sebesar-besarnya.

Bertitik tolak dari uraian diatas, maka perlu kiranya membuat suatu aplikasi mobile learning yang sesuai harapan siswa, yaitu membantu siswa dalam 


\section{Ira Wulan Sari', Sumuslistiana ${ }^{2}$}

memahami dan menyelesaikan permasalahan yang berkaitan dengan Program Linear, sehingga dapat meningkatkan hasil belajarnya. Aplikasi media pembelajaran tersebut dapat dipelajari oleh` para siswa secara mandiri kapan pun dan dimana pun melalui smartphone yang berbasis android tanpa harus mengaksesnya ke internet dan gratis. Dengan demikian tujuan dari penelitian ini adalah untuk mendeskripsikan aplikasi mobile learning berbasis android sebagai media pembelajaran yang berkualitas pada materi program linear di Kelas XI Sekolah Menengah Tingkat Atas Widya Dharma Surabaya. Adapun batasan dalam penelitian pengembangan ini, sebagai berikut: (a) Materi yang digunakan terbatas pada Program Linear Semester Gasal di kelas XI Sekolah Menengah Atas Widya Dharma Surabaya; (b) Aplikasi mobile learning berbasis android dengan menggunakan bahasa pemrograman tertentu untuk smartphone; serta (c) Penelitian ini, merupakan penelitian pengembangan produk, berupa aplikasi di smartphone yang dapat membantu belajar siswa dalam meningkatkan hasil belajar terkait program linear.

Kontribusi yang diharapkan dengan adanya penelitian pengembangan ini, adalah memberikan kemudahan bagi siswa SMA dan sederajat khususnya kelas XI SMA Widya Dharma Surabaya dalam mempelajari matematika khususnya pada materi Program Linear dengan memanfaatkan kecanggihan teknologi saat ini secara gratis melalui aplikasi mobile learning berbasis android sebagai media pembelajaran yang dapat dipelajari secara mandiri/kelompok, dimana pun dan kapan pun. Dapat juga sebagai salah satu alternatif media pembelajaran yang dapat membantu guru dalam melaksanakan kegiatan pembelajaran untuk mencapai tujuan pembelajaran.

\section{METODE PENELITIAN}

\section{Jenis Penelitian}

Jenis penelitian pengembangan atau disebut Research and Development (R\&D) dengan model Hannafin dan Peck, yang menurut Hasyim (2016) adalah model pengembangan yang digunakan dalam pengembangan produk pembelajaran berupa bahan ajar dalam bentuk cetak, audio, audiovisual, atau multimedia dan salah satu model desain pembelajaran sistematik. Metode 
pengembangan ini meliputi tiga fase, yaitu needs assess (analisis kebutuhan), design (desain), develop/implement (pengembangan atau implementasi). Pada langkah evaluasi fase ketiga, dilakukan uji coba terbatas.

\section{Subyek, Obyek dan Tempat Penelitian}

Subyek dalam penelitian ini adalah siswa kelas XI IPA 1 SMA Widya Dharma Surabaya sebanyak 20 orang dengan obyek penelitiannya berupa aplikasi mobile learning berbasis android pada materi program linear. Aplikasi tersebut dinamakan "Prolin Edu App". Para siswa tersebut dipastikan belum memperoleh materi program linear. Tempat pelaksanaan penelitian dilaksanakan dan difokuskan pada siswa kelas XI IPA 1 Sekolah Menengah Atas Widya Dharma Surabaya, Semester Gasal Tahun pelajaran 2018-2019 yang beralamat di Jalan Ketintang No. 147 - 151 Surabaya.

\section{Rancangan Penelitian}

Tahap rancangan pengembangan dalam penelitian ini mengacu pada model pengembangan Hannafin \& Peck. Model pengembangan ini meliputi tiga fase, yaitu needs assess (analisis kebutuhan), design (desain), develop atau implementation (pengembangan atau implementasi).

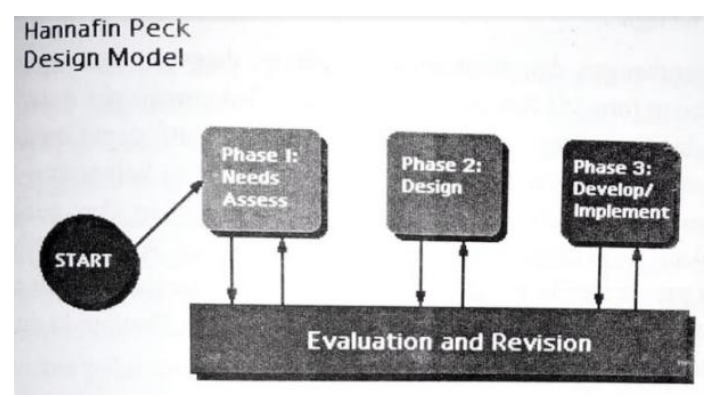

Gambar 1. Model Desain Pengembangan Hannafin dan Peck (Hasyim, 2016)

\section{Prosedur Penelitian}

Adapun prosedur dalam penelitian ini, sesuai tahapan model Hannafin dan Peck sebagai berikut:

a. Tahap Analisis kebutuhan, yaitu menentukan subyek penelitian dan mengumpulkan data awal guna mengetahui kesulitan siswa dalam mempelajari materi Program Linear (studi lapangan) dan kajian pustaka yang berkaitan dengan penelitian (studi pustaka). 
b. Tahap Perancangan, yaitu membuat perancangan melalui storyboard dan flowchart, sehingga menghasilkan sebuah produk berupa aplikasi mobile learning berbasis android

c. Tahap Pengembangan/Implementasi, yaitu memvalidasi aplikasi mobile learning berbasis android yang telah dibuat, oleh para validator untuk menghasilkan produk aplikasi yang layak digunakan; kemudian mengimplementasikannya dengan uji coba terbatas ke siswa; kemudian melakukan analisis mendalam terhadap data yang telah diambil; serta menarik kesimpulan dari analisis penelitian tersebut dan menyusun laporan penelitian.

\section{Metode Pengumpulan dan Analisis Data}

Metode pengumpulan dan analisis data dengan tujuan untuk melihat berkualitas baik tidaknya aplikasi media pembelajaran dengan berdasarkan Nieveen (2013) yaitu:

\section{Kevalidan perangkat,}

Metode validasi perangkat, untuk melihat valid tidaknya perangkat yang akan diujicobakan. Adapun perangkat yang divalidasi meliputi media pembelajaran berupa aplikasi mobile learning berbasis android termasuk tes hasil belajar. Analisis ini dilakukan setelah mendapatkan data hasil penilaian validasi ahli materi dan media, serta guru sebagai pengguna. Penilaian validasi tersebut, meliputi aspek-aspek: (a) Kualitas isi dan tujuan (terkait kejelasan dan relevansi rumusan capaian pembelajaran dengan KD dan KI, materi, pembahasan contoh, butir soal dengan urutan capaiannya, kunci jawaban dengan butir soalnya, kelengkapan dan kemutakhiran materi, dan bahasa yang komunikatif); (b) Kualitas teknis, (terkait keamanan, kemenarikan tampilan dan pemilihan warna, ukuran file aplikasi, proses instalasi aplikasinya, kejelasan petunjuk bantuan, tombol dan menu navigasi, kecepatan jalannya aplikasi, dapat digunakan di berbagai tipe handphone android, tidak menyebabkan handphone mengalami hang (berhenti), aplikasi ini mudah dibagikan ke handphone lainnya, kesesuaian proporsi gambar yang ditampilkan, penanganan terhadap penilaian latihan soal dan uji kompetensi cepat dan tepat; dan (c) Kualitas instruksional, (terkait ketertarikan dan termotivasinya siswa untuk belajar; kejelasn pengukuran kemampuan siswa 
dan keaktifan siswa, sarana berinteraksi, keleluasaan ruang dan waktu; Kemandirian belajar siswa; media pembelajaran yang baik)

Kegiatan yang dilakukan untuk menganalisis data ini adalah:

a. Merekap data validasi yang telah diisi oleh validator ke dalam tabel untuk dianalisis lebih lanjut.

b. Mencari rata-rata tiap kriteria dengan rumus:

$$
\bar{X}=\frac{\sum X}{N}
$$

Keterangan:

$\bar{X}=$ Skor rata-rata tiap kriteria

$\sum X=$ Jumlah skor

$N=$ Banyaknya validator

c. Data skor yang terkumpul diubah menjadi nilai kualitatif sesuai dengan kriteria yang telah ditentukan pada Tabel 1.

Tabel 1. Kriteria Penilaian

\begin{tabular}{ll}
\hline \multicolumn{1}{c}{ Interval Skor } & \multicolumn{1}{c}{ Kategori } \\
\hline$X>M i+1,5(S D i)$ & Sangat layak \\
$M i<X<M i+1,5(S D i)$ & Layak \\
$M i-1,5(S D i)<X<M i$ & Tidak layak \\
$X<M i-1,5(S D i)$ & Sangat tidak layak \\
\hline
\end{tabular}

(Mardapi, 2004)

Keterangan:

$M i=1 / 2($ skor maksimum + skor minimum $)$

$S D i=\frac{1}{6}($ skor maksimum - skor minimum $)$

Sehingga, validasi terhadap aplikasi dapat dikatakan valid jika dalam kategori minimal layak untuk digunakan sesuai saran.

\section{Kepraktisan}

Praktis dibagi menjadi dua aspek yaitu praktis secara teori dan praktis secara praktik. Praktis secara teori berdasarkan hasil penilaian umum yang dilakukan validator dalam validasi media berupa aplikasi mobile learning berbasis android, yaitu jika memenuhi syarat: hasil penilaian validator ahli materi dan media menyatakan bahwa aplikasi tersebut dapat digunakan dengan sedikit atau tanpa revisi. Sedangkan 
praktis secara praktik bergantung pada penilaian validasi oleh guru sebagai praktisi atau pengguna pertama, yaitu jika memenuhi syarat hasil penilaian guru sebagai pengguna pertama menyatakan bahwa aplikasi tersebut dapat digunakan dengan sedikit atau tanpa revisi

\section{Keefektifan}

Media pembelajaran berupa aplikasi mobile learning berbasis android dalam penelitian ini, dapat dikatakan efektif, maka metode pengumpulan datanya berupa tes hasil belajar dan angket respon siswa dengan analisisnya, sebagai berikut:

a. Untuk mengetahui terjadinya peningkatan hasil belajar siswa antara sebelum dan sesudah perlakuan, dengan menggunakan Data N-Gain yang dirumuskan sebagai berikut (Lestari dan Yudhanegara, 2017):

$\mathrm{N}$-gain $=\frac{\text { Skor postes }- \text { Skor pretes }}{\text { SMI-Skor Pretes }}$

Keterangan:

SMI = Skor Maksimum Ideal

Dengan kriteria nilai N-Gain diberikan pada Tabel 2.

Tabel 2. Kriteria Penilaian N-Gain

\begin{tabular}{cc}
\hline Nilai N-Gain & Kriteria \\
\hline$N-$ gain $\geq 0,70$ & Tinggi \\
$0,30<N-$ gain $<0,70$ & Sedang \\
$N-$ gain $\leq 0,30$ & Rendah \\
\hline
\end{tabular}

Sehingga, aplikasi yang dikembangkan dapat dikatakan efektif, berdasarkan rata-rata siswa sebagian besar memiliki nilai $\mathrm{N}$-Gain minimal dalam katergori sedang.

b. Untuk menganalisis data respon siswa, dengan menghitung respon siswa yang memberikan tanggapan sesuai dengan kriteria tertentu, dengan rumus:

$$
N R=\frac{\sum(R \times \text { skor pilihan jawaban })}{n . \text { skor maksimal }} \times 100 \%
$$

Keterangan:

$\mathrm{NR}=$ Nilai respon siswa

$\sum \mathrm{R}=$ Banyak siswa yang memilih jawaban tiap indikator 
Respon siswa setelah penggunaan aplikasi mobile learning berbasis android dapat dikatakan memiliki respon positif apabila rata-rata seluruh siswa merespon minimal $75 \%$ untuk setiap aspek yang direspon. Oleh karena itu, aplikasi mobile learning berbasis android yaitu "Prolin Edu App" dikatakan praktis dan efektif, jika rata-rata persentase respon siswa positif sebagai praktisi atau pengguna kedua.

\section{HASIL PENELITIAN DAN PEMBAHASAN}

Pengembangan aplikasi mobile learning berbasis android dalam penelitian ini mengacu pada model pengembangan Hannafin \& Peck, secara rinci fase pengembangannya, sebagai berikut:

\section{Needs Assess (analisis kebutuhan),}

Adapun hasil analisis kebutuhan diperoleh sebagai berikut:

a. Analisis siswa dilakukan untuk mengetahui karakteristik siswa dalam memahami materi yang diteliti. Berdasarkan wawancara dengan guru mitra, diperoleh bahwa semua siswa di sekolah tersebut memiliki kemampuan yang heterogen dengan rata-rata berlatar belakang ekonomi menengah ke bawah, namun hampir seluruh siswa memiliki smartphone berbasis android, sehingga mereka seluruhnya mampu menggunakan aplikasi yang berbasis android. Berdasarkan penyebaran angket secara random sebanyak 30 responden dari 60 siswa dalam kegiatan awal penelitian terhadap siswa kelas XI tahun pelajaran 2017/2018 yang lalu bahwa 67\% dari respon siswa mengaku pembelajaran matematika di sekolah cukup menyenangkan, dengan alasan tergantung dengan materi yang dibahas, sebagai besar persentase rata-rata siswa mengaku kesulitan dalam memahami dan memecahkan permasalahan pada materi program linear sebesar 46\%. Padahal, program linear merupakan salah satu materi penting dan sering digunakan dalam kehidupan nyata. Kesulitan siswa dalam mempelajari materi program linear ini, berdasarkan angket respon siswa tersebut adalah dalam menggambar grafik himpunan penyelesaian sistem pertidaksamaan linear dua variabel (hanya sebesar 43,33\% siswa yang 


\section{Ira Wulan Sari', Sumuslistiana ${ }^{2}$}

mampu); menerjemahkan persoalan program linear di kehidupan sehari-hari ke dalam model matematika (hanya sebesar $46,67 \%$ siswa yang mampu); dan menentukan nilai optimum dengan metode uji titik sudut maupun garis selidik (rata-rata hanya sebesar $41,67 \%$ ). Lebih lanjut, selama proses kegiatan pembelajaran pada materi program linear, guru mitra menggunakan media pembelajaran konvensional dan hanya menggunakan lembar kerja siswa yang telah direkomendasikan sebagai sumber belajar utama. Guru mitra juga belum pernah menerapkan mobile learning dalam kegiatan pembelajarannya. Berdasarkan pengamatan, terlihat bahwa setelah proses kegiatan belajar usai, para siswa di sekolah tersebut cenderung menggunakan handphone mereka untuk mengakses berbagai macam sosial media, bermain game, mendengarkan musik, ataupun bermain fitur hiburan lainnya. Sehingga, hal inilah yang menjadi salah satu penyebab menyita waktu belajar dan konsentrasi siswa terhadap pelajaran di sekolah. Tidak hanya di sekolah, para siswa bahkan menggunakan handphone mereka setiap saat, sehingga terkadang siswa enggan mempelajari kembali dan enggan pula mengerjakan tugas rumah yang ditugaskan oleh guru mereka di sekolah. Hal inilah yang salah satu penyebab sebagian siswa menjadi kurang mampu memahami dan memecahkan masalah khususnya materi program linear. Dari permasalahan diatas, dapat diantisipasi dengan pembuatan media pembelajaran yang memanfaatkan smarthphone yang berbasis android, mengingat sebagian besar siswa memilikinya.

b. Pembuatan dan pengembangan media pembelajaran dengan memanfaatkan teknologi berupa aplikasi mobile learning berbasis android pada materi program linear ini diharapkan dapat meningkatkan kualitas proses belajar siswa, baik di sekolah ataupun di luar sekolah;membuat siswa tertarik dan berminat untuk belajar; proses penyebaran aplikasi mobile learning berbasis android ini juga mudah yaitu dapat melalui kabel data, bluetooth, email,grup sosial media seperti whatshap, dan sebagainya.

c. Pembuatan media pembelajaran berupa aplikasi mobile learning berbasis android ini (Prolin Edu App) menggunakan perangkat keras (hardware) dan perangkat lunak (software), adapun macamnya yaitu: Perangkat keras (hardware) yang digunakan untuk membuat media pembelajaran ini adalah: 
Laptop Toshiba Core i3 dan Smartphone Android. Sedangkan, perangkat Lunak (Software) digunakan untuk membuat media ini dibagi menjadi beberapa macam, diantaranya: Sublime Text 3, Phone Gap, dan Paint, Geogebra, jQuery Mobile, Slick Quiz jQuery Plugin, serta yang lainnya menggunakan coding manual.

d. Kurikulum yang berlaku di tempat penelitian adalah Kurikulum 2013. Pada kurikulum ini, materi program linear disampaikan kepada siswa SMA/Sederajat di kelas XI.

Berdasarkan analisis kebutuhan tersebut, alternatif solusinya adalah dengan mengembangkan sebuah media pembelajaran berupa aplikasi mobile learning berbasis android pada smartphone mereka, dimana siswa dapat dengan mudah mempelajari baik secara mandiri atau berkelompok khususnya materi program linear, dimana pun dan kapan pun, baik untuk mengingat kembali ataupun siswa yang pada saat itu akan memperoleh pembelajaran materi tersebut.

\section{Design (desain)}

Pada fase ini merupakan fase perencanaan dan perancangan aplikasi yang meliputi: pembuatan desain aplikasi secara keseluruhan dalam bentuk story board dan penyusunan isi materi pada aplikasi yang akan dibuat. Setelah story board dibuat, kemudian hasilnya didiskusikan dengan programmer untuk dievaluasi dan direvisi, sehingga menghasilkan story board yang lebih baik.

Gambar logo dari aplikasi mobile learning berbasis android yang dikembangkan dan dinamakan "Prolin Edu App" diberikan pada Gambar 2.

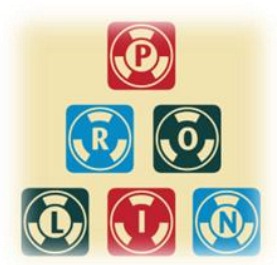

Gambar 2. Logo Aplikasi yang Dikembangkan

\section{Develop/implement (pengembangan atau implementasi)}

Dari hasil fase desain, fase selanjutnya adalah fase pengembangan. Pada fase ini, dibuat diagram alir dari storyboard pada fase sebelumnya untuk 
menghasilkan media pembelajaran yang dikehendaki berupa aplikasi mobile learning berbasis android dan dinamakan "Prolin Edu App".

Pada fase pengembangan dan implementasi ini, juga dilakukan pengujian terhadap aplikasi yang sudah dibuat termasuk didalamnya butir soal tes hasil belajar berupa uji kompetensi untuk melihat valid tidaknya dan layak digunakan atau tidaknya. Penilaian ini dilakukan oleh tiga validator ahli materi dan media yang berkompeten dibidangnya. yang terdiri dari: (1) validator I bernama Rachmaniah Maiza, M.Pd merupakan mahasiswa S3 Pascasarjana Surabaya; (2) validator II bernama Endang Krisnawati, M.Pd yang merupakan dosen pendidikan matematika di STKIP Bina Insan Mandiri Surabaya; dan (3) validator III bernama Suratman, S.ST, S.Pd yang merupakan guru jurusan teknologi jaringan di SMK Negeri I Surabaya.

Setelah proses pengujian kepada ketiga validator, hasil pada tahap tersebut dievaluasi dan direvisi sampai menghasilkan kevalidan dan kelayakan media pembelajaran berupa aplikasi mobile learning berbasis android yang dikehendaki. Tahap selanjutnya adalah penilaian sumatif dan formatif yang dilakukan pada ujicoba terbatas. Berikut ini penjelasan hasil penelitian pengembangan aplikasi Draft I ke Draft II.

a. Deskripsi hasil pengembangan aplikasi Draft I ke aplikasi Draft II

Awal dari fase pengembangan berupa aplikasi Draft I merupakan media pembelajaran yang pertama dirancang dan dibuat oleh peneliti dibantu seorang programmer yang berkompeten dibidangnya. Setelah Draft Produk I dirancang dan dibuat, untuk menentukan kualitasnya sebagai media pembelajaran yang berkualitas baik,maka diperlukan evaluasi oleh validator ahli media dan materi berupa respon,saran dan komentar, sebelum diujicobakan ke siswa sebagai pengguna. Hasil validasi dari validator ahli media dan materi tersebut kemudian dianalisis dan direvisi sehingga menghasilkan Draft Produk II, dan seterusnya sampai validator menyatakan "valid dan layak" untuk dilakukan uji coba terbatas.

Seperti dijelaskan terkait teknik analisisnya, maka hasil rekapitulasi analisis dari ketiga validator tersebut diberikan pada Gambar 3, 4, dan 5. 


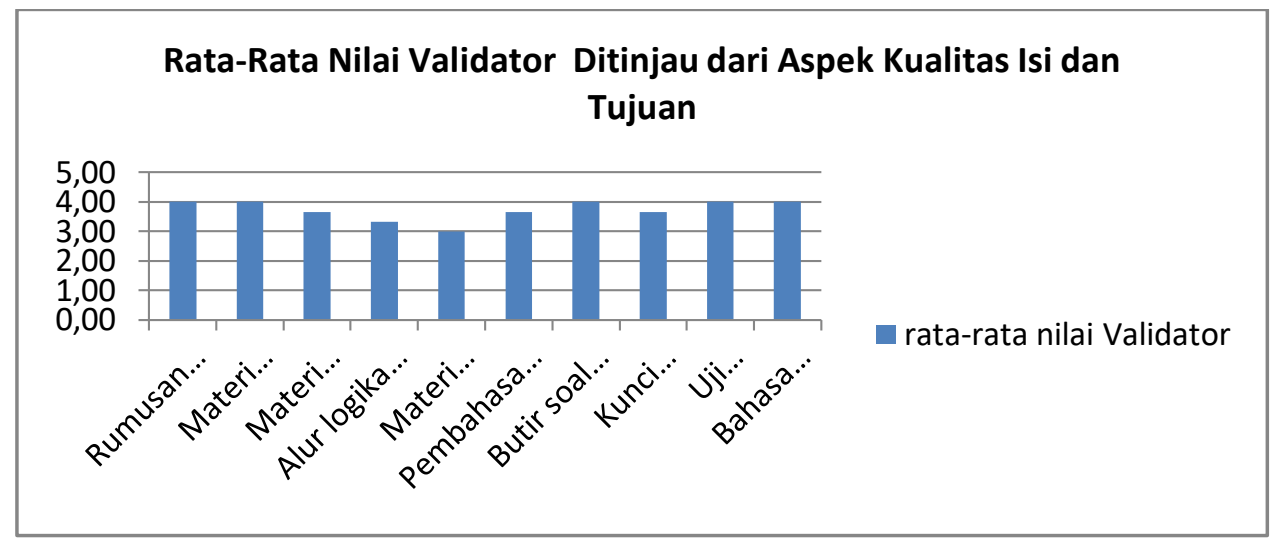

Gambar 3. Rata-Rata Nilai Validator Ditinjau dari Aspek Kualitas Isi dan Tujuan

Dari hasil analisis terlihat bahwa, dari 10 indikator dari aspek kualitas dan isi, ada 4 indikator berada pada kriteria "layak", dan 6 indikator berada pada kriteria "sangat layak". Dengan demikian, nilai rata-rata seluruh indikator pada aspek kualitas isi dan tujuan sebesar 3.37 dan termasuk kedalam kriteria "sangat layak".

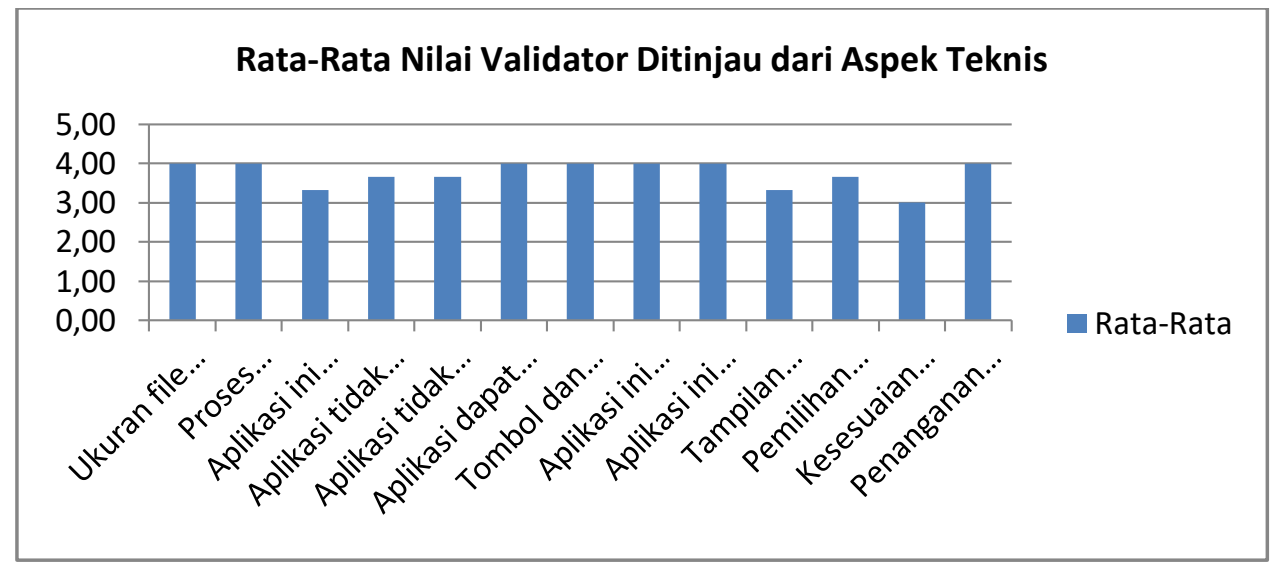

Gambar 4. Rata-Rata Nilai Validator Ditinjau dari Aspek Teknis

Dari hasil analisis terlihat bahwa, dari 13 indikator dari aspek teknis, ada 4 indikator berada pada kriteria "layak", dan 9 indikator berada pada kriteria "sangat layak". Dengan demikian nilai rata-rata seluruh indikator pada aspek kualitas teknis sebesar 3.56 dan termasuk kedalam kriteria "sangat layak". 


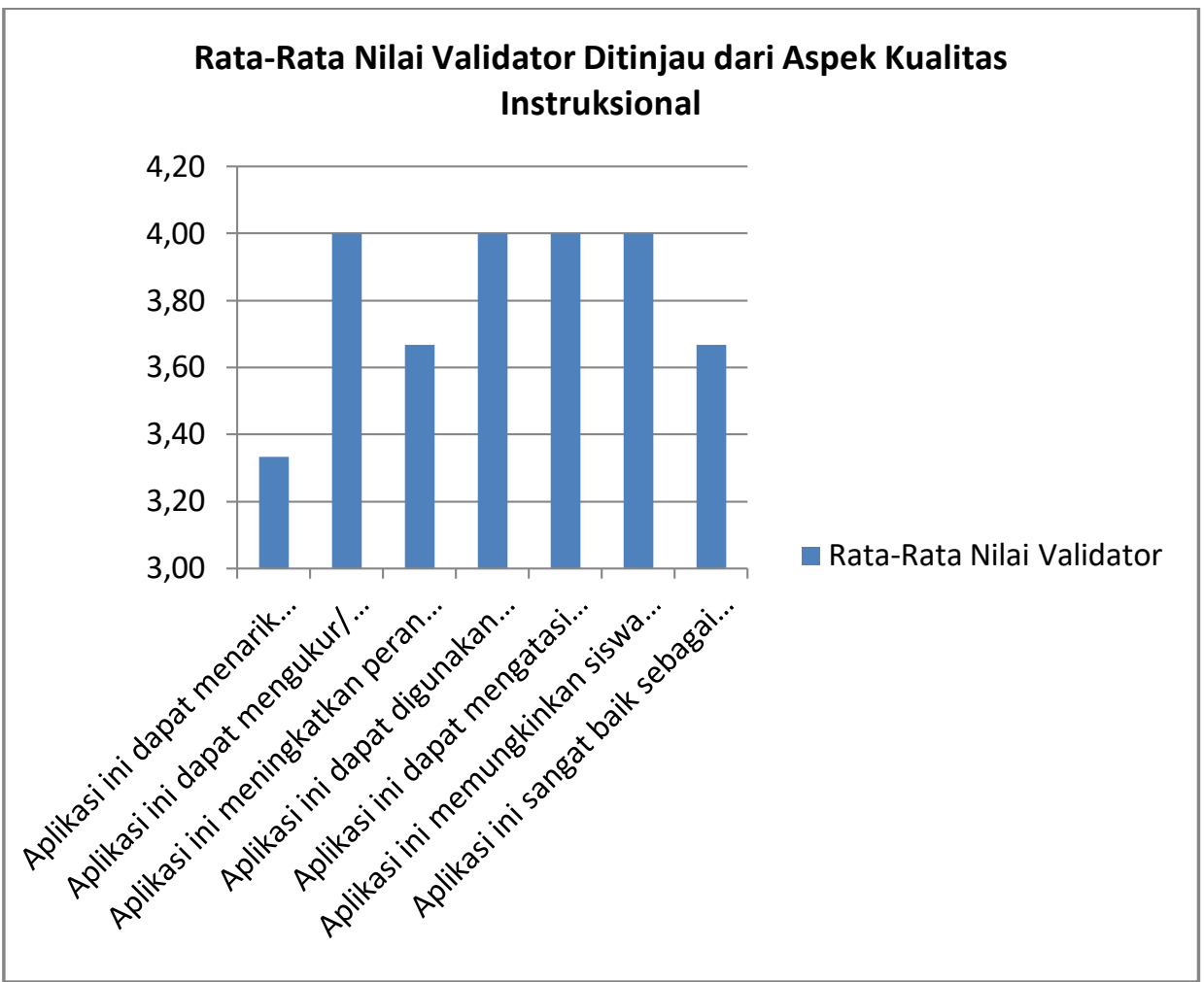

Gambar 5. Rata-Rata Nilai Validator Ditinjau dari Aspek Kualitas Instruksional

Dari hasil analisis terlihat bahwa, dari 7 indikator dari aspek instruksional, ada 5 indikator berada pada kriteria "layak", dan 2 indikator berada pada kriteria "sangat layak". Dengan demikian nilai rata-rata seluruh indikator pada aspek instruksional sebesar 3.19 dan termasuk kedalam kriteria "layak".

Berdasarkan analisis diatas dan kesimpulan pada lembar validasi ketiga validator menunjukkan bahwa layak digunakan dengan revisi sesuai saran. Lebih lanjut, analisis hasil validasi isi dari ketiga validator terkait kisikisi instrument uji kompetensi dan butir soal uji kompetensi di dalam aplikasi yang dikembangkan,menunjukkan bahwa menurut hasil penilaian para ahli/validator terhadap tes hasil belajar secara umum sebanyak 10 butir adalah valid, dapat dipahami, dan dapat digunakan dengan tanpa revisi.

Revisi yang dilakukan terhadap Butir soal Uji Kompetensi ini berdasarkan komentar dan saran-saran para validator. Dari hasil penilaian dari para validator ahli materi dan media, aplikasi Draft produk I termasuk di 
dalamnya uji kompetensinya diperbaiki kembali dibantu oleh programmer menjadi sebuah aplikasi Draft produk II.

b. Deskripsi hasil implementasi aplikasi Draft Produk II

Draft produk II sebelum diujicobakan kepada siswa, dilakukan penilaian validasi oleh guru mitra yang bernama Ibu Suharni, S.Pd merupakan guru matematika SMA Widya Dharma Surabaya dan sebagai praktisi/pengguna pertama.

Penilaian validasi guru terhadap aplikasi Draft Produk II ditinjau dari aspek kualitas isi dan tujuan menunjukkan bahwa terdapat 3 indikator dalam kriteria "sangat layak" dan 5 indikator dalam kriteria "layak". Nilai rata-rata dari aspek kualitas isi dan tujuan sebesar 3,375 dan termasuk dalam kriteria "sangat layak".

Penilaian guru terhadap aplikasi Draft Produk II ditinjau dari aspek kualitas isi dan tujuan menunjukkan bahwa terdapat 9 indikator dalam kriteria "sangat layak" dan 4 indikator dalam kriteria "layak". Nilai rata-rata dari aspek kualitas isi dan tujuan sebesar 3,69 dan termasuk dalam kriteria "sangat layak".

Penilaian guru terhadap aplikasi Draft Produk II ditinjau dari aspek kualitas instruksional menunjukkan bahwa seluruh indikator berada dalam kriteria "layak". Sehingga Nilai rata-rata dari aspek kualitas instruksional ini sebesar 3 dan termasuk dalam kriteria "layak" pula. Dengan demikian nilai rata-rata ketiga aspek yaitu isi dan tujuan, teknis dan instruksionalnya sebesar 3,36 dalam kriteria "sangat layak". Dan kesimpulan dalam penilaian guru mitra bahwa aplikasi ini, termasuk materi, latihan soal dan uji kompetensi didalamnya dapat digunakan tanpa revisi, sehingga dapat diujicobakan secara terbatas kepada para siswanya.

c. Deskripsi hasil uji coba terbatas

Sebelum dilakukan uji coba dengan mobile learning ini, pada pertemuan I, tanggal 29 Agustus 2018, para siswa kelas XI MIA 1 diberikan pretes untuk mengetahui kemampuan awalnya terkait materi program linear. Dari hasil prestes terlihat, paling banyak siswa mengerjakan hanya sampai 
pada 2 butir soal dari 10 butir soal dan belum tentu semua jawabannya bernilai benar. Selanjutnya pertemuan II, pada tanggal 4 September 2018 dibagikan dan diinformasikan penggunaan program aplikasi tersebut kepada seluruh siswa di kelas. Dari 20 siswa, ada 1 siswa yang tidak bisa memasukkan aplikasi tersebut di alat komunikasinya yang berjenis Samsung Tab 3Lite, sehingga siswa tersebut diminta untuk bergabung dengan teman sebangkunya. Selanjutnya, memberi kesempatan kepada para siswa untuk mempelajarinya melalui aplikasi tersebut, kemudian dilakukan diskusi dan tanya jawab seputar materi tersebut. Selama proses pembelajaran, terlihat bahwa seluruh siswa di kelas tersebut, bersemangat untuk mengikuti pelajaran, hal ini dikarenakan belajar melalui media aplikasi mobile learning merupakan hal yang baru bagi mereka. Di akhir pembelajaran, dijelaskan bahwa aplikasi tersebut dapat dipelajari kembali, dimana pun dan kapan pun. Pada pertemuan III, tanggal 06 September 2018, dibahas pelajaran yang sudah dipelajari sebelumnya untuk beberapa waktu, kemudian dilanjutkan dengan pemberian postes dan angket.

Setelah pelaksanaan penelitian, maka data yang terkumpul kemudian dianalisis, berikut hasil analisis dan pembahasannya:

a) Berdasarkan hasil analisis pre-test dan post-test menunjukkan bahwa terjadi peningkatan nilai pre-test sebelum dilaksanakan penelitian dan nilai post-test setelah dilaksanakan penelitian. Grafik hasil peningkatan hasil belajar dengan perhitungan N-Gain diberikan pada Gambar 6.

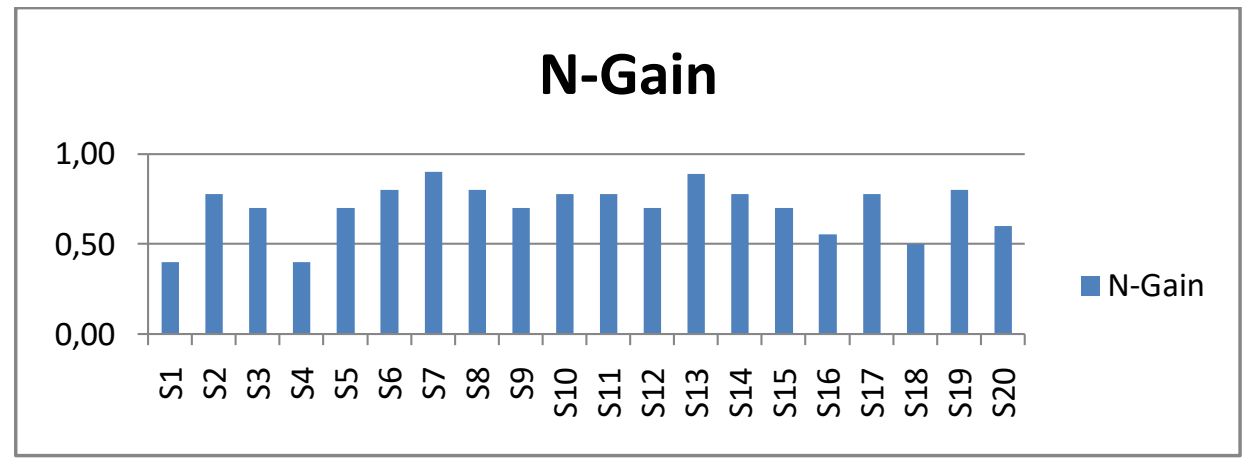

Gambar 6. Hasil Peningkatan Hasil Belajar dan Perhitungan N-Gain. 
Seluruh Siswa Kelas XI SMA Widya Darma Surabaya memiliki nilai NGain minimum sebesar 0.40 dan maksimum sebesar 0.90 dengan Kriteria "sedang" dan "tinggi". Dengan, rata-rata nilai N-Gain seluruh siswa di kelas tersebut sebesar 0.70, dengan kategori "tinggi", maka dapat dikatakan penggunaan terhadap aplikasi tersebut dapat dikatakan efektif.

b) Setelah berakhirnya kegiatan pembelajaran, siswa diberi angket untuk melihat respon/tanggapan mereka terkait penggunaan aplikasi yang telah mereka lakukan. Adapun hasilnya sebagai berikut:

1) Persentase rata-rata hasil respon siswa, berdasarkan seluruh indikator dari aspek kualitas isi dan tujuan sebesar $81 \%$. Sedemikian sehingga berdasarkan teknik analisis, dapat disimpulkan bahwa hasil respon siswa ditinjau dari aspek kualitas isi dan tujuan memenuhi kriteria respon positif.

2) Persentase rata-rata hasil respon siswa, berdasarkan seluruh indikator dari aspek kualitas teknis sebesar 82\%. Sedemikian sehingga berdasarkan teknik analisis, dapat disimpulkan bahwa hasil respon siswa ditinjau dari aspek kualitas teknis memenuhi kriteria respon positif.

3) Sedangkan persentase rata-rata hasil respon siswa, berdasarkan seluruh indikator dari aspek kualitas Instruksional sebesar 83\%. Sedemikian sehingga berdasarkan teknik analisis, dapat disimpulkan bahwa hasil respon siswa ditinjau dari aspek kualitas instruksional memenuhi kriteria respon positif.

Dengan demikian, dapat dilihat rata-rata persentase hasil respon siswa siswa kelas XI terhadap penggunaan aplikasi mobile learning berbasis android pada materi program linear dari ketiga aspek kualitas, baik isi dan tujuan; teknis serta instruksionalnya, sebesar $82 \%$, hal ini memenuhi kriteria respon positif terhadap penggunaan aplikasi tersebut. 


\section{SIMPULAN}

Penyebab kesulitan belajar siswa dalam mempelajari materi program linear yang terdapat pada analisis kebutuhan adalah siswa hanya memiliki lembar kerja siswa yang direkomendasikan oleh guru, dikarenakan dari segi perekonomian, rata-rata para siswa tergolong berada di kelas menengah ke bawah, meskipun demikian hampir sebagian besar siswa memiliki smartphone. Selain itu, metode pembelajaran yang digunakan oleh guru, kurang bervariasi dan belum pernah menggunakan mobile learning dalam pembelajarannya. Kesulitan yang rata-rata siswa dalam mempelajari materi program linear adalah ketika menggambar grafik himpunan penyelesaian sistem pertidaksamaan linear dua variabel; menerjemahkan persoalan program linear di kehidupan sehari-hari ke dalam model matematika; dan menentukan nilai optimum dengan metode uji titik sudut maupun garis selidik.

Setelah diperoleh hasil pada tahap analisis kebutuhan, maka dikembangkan produk pada tahap perancangan (Design) sampai pada tahap pengembangan (Develop/Implementation), hasilnya meliputi: (a) Aplikasi dikatakan valid oleh para validator ahli materi dan media; (b) Aplikasi dikatakan praktis oleh pengguna pertama melalui hasil penilaian aplikasi oleh pengguna pertama (guru) yang valid dan memenuhi kelayakan untuk digunakan baik oleh para validator ahli materi dan media, serta pengguna pertama (guru); (c) Aplikasi dikatakan efektif oleh pengguna kedua (siswa) melalui hasil rata-rata uji kompetensi berdasarkan perhitungan $\mathrm{N}$-Gain berkriteria tinggi, dan hasil rata-rata angket respon siswa yang positif.

Dengan demikian, maka media pembelajaran yang dikembangkan dalam penelitian ini, yaitu berupa aplikasi mobile learning berbasis android ini yang bernama Prolin Edu App dapat dikatakan berkualitas baik.

\section{DAFTAR PUSTAKA}

Ally, Muhamed. (2009). Mobile learning: transforming the delivery of education and training. Québec: AU Press.

Hasyim, Adelina. 2016. Metode Penelitian dan Pengembangan di Sekolah. Yogyakarta: Media akademi. 
Kemdikbud. 2013. Aplikasi Mobile Tutorial Matematika. www.kesekolah.com/tutorial/tutorial-matematika.html. Diakses 15 April 2015.

Mardapi, Djemari. (2004). Penyusunan Test Hasil Belajar. Yogyakarta.

Nieveen,dkk. 2013. Educational Design Research. Enschede: SLO.

Purbasari, Rohmi Julia. 2013. Pengembangan Aplikasi Android sebagai Media Pembelajaran Matematika pada Materi Dimensi Tiga untuk Siswa SMA Kelas X. Skripsi: Jurusan Pendidikan Matematika FMIPA Universitas Negeri Malang (tidak dipublikasi).

Safaat, Nazrudin. 2012. Pemograman Aplikasi Mobile Smartphone dan Tablet PC Berbasis Android. Bandung: Informatika. 